\title{
THE SEARCH FOR BALANCE AND EQUILIBRIUM OF NEGOTIATING POWERS UNDER DISTORTED MARKET COMPETITION
}

\author{
Kęstutis Peleckis ${ }^{1, a}$, Valentina Peleckiene ${ }^{2, b, *}$ and Kęstutis Peleckis ${ }^{3, c}$ \\ ${ }^{1}$ Department of Business Technologies and Entrepreneurship, Vilnius Gediminas Technical \\ University, Saulètekio ave. 11, LT-10223 Vilnius, Lithuania \\ ${ }^{2}$ Department of Management, Vilnius Gediminas Technical University, Sauletekio ave. 11, LT-10223 \\ Vilnius, Lithuania \\ ${ }^{3}$ Department of Economics Engineering. Vilnius Gediminas Technical University, Sauletekio ave. 11, \\ LT-10223 Vilnius, Lithuania \\ akestutis.peleckis@vgtu.lt, ${ }^{b} v a l e n t i n a . p e l e c k i e n e @ v g t u . l t,{ }^{c k}$.peleckis@vgtu.lt \\ *Corresponding author
}

Cite as: Peleckis, K., Peleckiene, V., Peleckis, K. (2018). The search for balance and equilibrium of negotiating powers under distorted market competition. Ekonomicko-manazerske spektrum, 12(2), 6782.

Available at: dx.doi.org/10.26552/ems.2018.2.67-82

\begin{abstract}
Free market economy challenges business negotiations due to occasional distortions in market conditions, which impact the balance of negotiating powers. This is most commonly referred to both buyers and sellers. Reducing the negative impact of the distorted competition opens great opportunities for international business relations as new market participants can create additional alternatives for organizations trying to reach the balance of negotiating powers. The assessment of the negotiation powers of the negotiating parties is crucial for the development and implementation of effective international business negotiation strategies in order to make the best use of the negotiation potential. The purpose of this article is to fully explore the current theory and practice of the development and implementation of negotiating strategies under distorted market competition, as well as to reveal development opportunities of these strategies in cases of monopsony, oligopsony and monopoly. The object of the research is to find a way to achieve the balance of negotiating powers at international business negotiations under distorted market competition. The scientific problem is that theory of negotiations is lacking in measures for assessment and balancing the negotiating powers of negotiation participants under distorted market competition. The goal of the article is to identify the key elements for determining the balance and equilibrium of negotiating powers at international business negotiations. Also it is important to find the opportunities for adequate evaluation the key elements, which affects the performance of international business negotiations.
\end{abstract}

Keywords: negotiation, negotiation strategy, negotiation power, the balance of negotiating powers, distorted competition,

JEL Classification: F51, M16

\section{Introduction}

Distorted market competition poses new challenges for business negotiations. It affects the balance of negotiating powers among negotiation participants. Such situations often result in 
negative consequences for both buyers and sellers. As a result, it opens additional opportunities for international business, because of the emergence of other market participants in the relevant markets, which can provide additional alternatives for both buyers and sellers by reducing the negative impact on the distortion of competition and balancing the negotiating powers of the negotiating parties. (Kiryluk-Dryjska, 2016, Brett \& Thompson, 2016, Przybyła-Kasperek \& Wakulicz-Deja, 2016, Schaerer et al., 2016, Ghavami et al., 2016, Rufo et al., 2016, Jäger et al., 2017) The development and implementation of an effective international business negotiation strategy, as well as the assessment of the negotiating powers among negotiating parties and the essential components of their deviation from balance is important for the effective use of the potential of business negotiations - the negotiating power. When solving the scientific problem, it is necessary to ensure that its solutions help to consider the balance of negotiating power among negotiation participants, allowing them to achieve the balance and to ensure the most efficiency of the development and implementation of their negotiation strategy.

A higher number of sellers and suppliers, allows the buyer to enjoy a greater variety of solutions and more alternatives. In such case, the buyer can take advantage of competitive tension. However, the situation in the absence of competitive tension is completely different. One of the reasons resulting in a lack of competitive tension in the market is that the number of suppliers is not sufficient to create a free and open competition, for example, in case of a monopoly. Therefore, we could define market distortion as the absence of free and open competition. Free competition means that market participants are competing with each other, instead of cooperating to create and maintain a cartel. Open competition means that the market entry barriers are sufficiently low, thus making the profits of existing players rather low, because otherwise new entrants coming into the market would try to sell with lower profits, which would essentially be useful for customers and thus ensure their sales.

There are two types of buyer power: the power, arising from the nature of the market (monopsony, oligopsony and monopoly markets), and the negotiating power. If the buyer can reduce the price to the level lower than the market competition among suppliers, it means that he has the monopsony power. Negotiating power depends on the bargaining strength, demonstrated by the buyer during communication and negotiations with suppliers. Monopsony power makes getting a lower price easier than using negotiating power. Negotiating power is used only when the supplier has a corresponding market power, which can be levered with negotiating power. The consequences of using negotiating power in each case are very different. In cases of monopsony and oligopsony markets, buyers' powers decrease the volume of sales and productivity in the supply market, which ultimately has a negative effect on the consumer market. The negotiating power of the buyer is more of a compensatory nature. It increases the volume of production in the supply market and can improve the market situation in the consumer market.

Object of the scientific article is the search for balance of negotiating powers at international business negotiations under distorted market competition. The purpose of the research is to perform a complex analysis of the current theory and practice in developing and implementing international business negotiations and negotiating strategies under distorted market competition, as well as to reveal improvement opportunities for development and implementation of these strategies in cases of monopsony, oligopsony and monopoly.

The scientific problem is that negotiation theory lacks measures to assess and balance the negotiating powers of negotiation participants under distorted market competition. The relevance of the study and the level of research. The relevance of this study has both theoretical and practical aspects. The theoretical relevance is related to the assessment and 
development of negotiating power among participants at international business negotiations, as well as the scientific search for measures to ensure their effectiveness and the development of a scientifically-based, sustainable and effective negotiation power balancing system. Such a system could improve the efficiency of negotiating teams in distorted market competition. The practical relevance is related to challenges of organizing business, increasing purposefulness of recent developments, which unfolds in increasing numbers of alternative business solutions and the need to search for new business partners, leading to greater expedience of business transactions, their efficiency and, ultimately, increasing the competitiveness of businesses entities in international business environment. Thus theoretical and practical relevance of this research can be characterized by the need to find and create a scientific basis for measures used for balancing negotiating powers among participants at business negotiations. They should help make an objective assessment of the negotiating powers and relationships between international business negotiation participants and their competitors, purposefully and effectively forming and using the negotiating powers of the negotiating team. These measures should guarantee a successful development and implementation of an effective business negotiation strategy in the context of international business development and increase its competitiveness, taking into account the circumstances, which distort market competition.

In scientific literature, the implementation of effective business negotiation strategies was researched by the following authors: Mazeikiene et al. (2012, 2010), Moosmayer et al. (2013), Wilken et al. (2013), Khakhar \& Rammal (2013), Przybyła-Kasperek \& Wakulicz-Deja (2016), Schaerer et al. (2016), Schaerer et al. (2016), Peleckis (2016), Dinkevych et al. (2016), Dunne et al. (2016), Ghavami et al. (2016), Weiss (2017).

The importance of searching for alternatives of strengthening negotiating power was highlighted by a number of scientists: Mazeikiene et al. (2010), Mazeikiene \& Peleckis (2009, 2010, 2012), Antaki \& Kent (2015), Petriwskyj et al. (2015), Alavoine \& Estieu (2015), Kiryluk-Dryjska (2016), Brett \& Thompson (2016), Przybyła-Kasperek \& Wakulicz-Deja (2016), Schaerer et al. (2016), Peleckis (2016), Ghavami et al. (2016), Rufo et al. (2016), Jäger et al. (2017).

Distorted market competition and its circumstances were researched by the following scientists: cases of monopsony - Dassiou \& Glycopantis (2008), The Organisation for Economic Co-operation and Development (OECD) (2008), Matsudaira (2014), Danziger (2010), Bonanno \& Lopez (2012), Strobl \& Walsh (2007), Barr \& Roy (2008); Rotemberg (2008), Brennan (2011), Walsh (2016), cases of monopoly - Mirman et al. (2014), Rogers (2013), Braido \& Shalders (2015), Sarafopoulos (2015), Jablanovic (2013), Willington \& Ning (2014), Mumuni et al. (2016), Lai et al. (2016), Mendoza (2016), Szidarovszky (2015), Kovac \& Zigic (2016), Shin (2017).

\section{Methodology}

The research methodology consisted of three parts. In the first part we analysed monopsony and the buyer's power, in the second - monopsony power forces and in the third part the cases of monopsony were analysed.

\subsection{Monopsony and the Buyer's Power}

Monopsony power is a mirror reflection of the power of a monopoly: it is the buyer's market power, as opposed to the seller's market power. (Dassiou \& Glycopantis, 2008, Matsudaira, 2014, Danziger, 2010, OECD, 2008; Bonanno \& Lopez, 2012, Strobl \& Walsh, 
2007, Barr \& Roy, 2008, Rotemberg, 2008, Brennan, 2011, Strobl \& Walsh, 2016) Monopsony power can be determined directly and indirectly. In cases of the former, it is determined by comparing the competitive market price with the price obtained by the buyer. The level of the prevailing market prices, determined by competing companies, does not reflect the actual purchase price. Meanwhile, the indirect monopsony power assessment method includes such factors as the market, market segments, entrance barriers and other relevant factors.

The buyer power is related to the way how purchasing companies may affect the trade relations with sellers and suppliers. The buyer power can manifest both through monopsony power and through the buyer's negotiating powers. The difference between these two types of buyer power is based on the structure of their sources and the entirety of the measures.

A business entity is considered as having monopsony powers, when the share of its purchases in the market is relatively high and when it can influence the price according to the sales volumes. The differences in the use of the negotiating power show on the level of discounts obtained. The negotiating power of the buyer shows his bargaining strength in relation with the supplier. Both types of buyer power opens the way to the level of lower sales prices. In case of monopsony power this can be achieved by emphasizing lower purchase volumes, when the negotiations involve expressing intensions to buy less. (Brennan, 2011, Strobl \& Walsh, 2016) The main difference with the case of monopsony power is that this case involves reducing prices below the competitive level, while in case of negotiating power, the seller still operates on a competitive level. (OECD, 2008, Bonanno \& Lopez, 2012, Strobl $\&$ Walsh, 2016) Monopsony and oligopsony powers (assuming that there is no price discrimination) lead to market distortions. As a rule, that is detrimental both to direct sellers and suppliers, as well as further links of the supply chain. (Matsudaira, 2014, Danziger, 2010, OECD, 2008)

Monopsony power supply in the market transfers the profit from supplier to buyer. Business entities with monopsony power behave as if they had higher marginal costs compared to companies that do not possess monopsony power. This ultimately increases the price for the end user, even if the costs are actually lower. Owning market power in the supply market as well, monopsonists do even more damage than if it they wouldn't.

Customers using negotiating power as a compensatory element (for example, where their negotiating power fully or partially compensates the market power of sellers) may increase the volume of production in the market and make the final consumers in the market better off. The extent to which customers can benefit from the negotiating power depends on the nature of contracts with suppliers and the level of competition in the consumer market. Increased consumer competition and their extent result in this negotiating power earning greater discounts for a wholesale price and bringing greater benefit to the consumers. (OECD, 2008, Bonanno \& Lopez, 2012, Strobl \& Walsh, 2007)

The research of monopsony power in practice shows that it may be determined by available alternatives for the sellers, which determine the volume of the buyers' monopsony power. If finding alternative buyers is easy, then their monopsony power is limited. Other sellers may be located in different geographical regions, be engaged in different activity and have different market needs, but their products may still be able to satisfy the same needs. Also, when searching for new markets, it is important to identify the presence of monopsony power in smaller geographic areas with a smaller number of products, where a hypothetical monopsonist could influence the price drop in that territory. (Antaki \& Kent, 2015, Petriwskyj et al., 2015, Przybyła-Kasperek \& Wakulicz-Deja, 2016, Schaerer et al., 2016, Ghavami et al., 2016, Rufo et al., 2016, Jager et al., 2017) 
When the number of buyers and sellers is small, negotiations between buyers and sellers (according to their capabilities) may also take place regarding the possible excess profit. The allocation of excess profit depends on the relative negotiating power. This excess profit is the objective of the buyers and sellers, thus motivating them to come into an agreement without looking for alternatives. The more efficiency buyers show in their negotiations, the more alternatives they have, resulting in fewer alternatives for the sellers and getting a larger share of the excess profit. Buyers' profit from transactions depends on their ability and willingness to look for alternative suppliers. Similarly, sellers' profit gained from transactions depends on their ability and willingness to look for other buyers. The essential factor influencing the negotiating power and showing that buyers have more alternatives than sellers is that buyers can easily switch suppliers without incurring significant additional costs (buyers act as consumer market intermediaries). (Matsudaira, 2014, Danziger, 2010, OECD, 2008, Bonanno \& Lopez, 2012, Rotemberg, 2008, Brennan, 2011, Strobl \& Walsh, 2016)

\subsection{Evaluation of Monopsony Power}

Monopsony power is influenced by the current suppliers' model. Suppliers' market models can be divided into Ricardian, Quasi or Monopoly models. (Matsudaira, 2014, Danziger, 2010, OECD, 2008, Bonanno \& Lopez, 2012, Strobl \& Walsh, 2007, Barr \& Roy, 2008, Rotemberg, 2008, Brennan, 2011, Strobl \& Walsh, 2016)

1. The Ricardian model refers to suppliers using differentiated supply of raw materials. In this case, the monopsony power depends on the flexibility of supply. More flexibility means greater opportunity to use the monopsony power, which determines production output disruptions in the supply market and is harmful to the end users. In the supply market companies with monopsony powers tend to behave in a way as if they experienced more costs than companies without monopsony powers. Monopsonistic power in supply market harms both productivity of suppliers and consumers. Possessing monopsony powers makes it necessary to recognize, whether your seller has an alternative, which is what determines the monopsony power. Monopsony power is limited if the seller can easily find other buyers in the local market or other geographical areas, or customers who would use these products as substitutes.

2. The Quasi model refers to the difference between total revenues and short term expenditures. A monopsonist can use this in the short term. In the long term, any attempt to use suppliers' situation may encourage them not to conclude a deal: the suppliers would not be able to get a return on their investments. If suppliers' market is engaged in fair competition, monopsonists will not be able to use their monopsony power in the long term.

3. In case of Monopoly model, suppliers and buyers will be more inclined to maximise the total profit for both sides, rather than refuse to cooperate. The creation of compensatory power in case of Monopoly model may lead to smaller prices for the end users. However, if one of the participants withdraws, such a case could lead to a failure of the deal. This would encourage the buyer to look for other markets.

\subsection{Cases of Monopsony}

Oligopsony among buyers. Oligopsony among buyers and high level of supply frequently results in Nash equilibrium. In cases of Nash equilibrium in procurement, all buyers define their product value according to the values determined by all buyers. Nash equilibrium will enable to exploit buyers' market power, which will depend on the product threshold value, the number of competing buyers and the flexibility of supply. (Dassiou \& Glycopantis, 2008, Matsudaira, 2014, Danziger, 2010) 
Cartel monopsonists. Oligopsonic Nash equilibrium does not maximize customer profits, resulting in a need to coordinate purchases by exploiting the collective market power, increasing profits, reducing purchases and selling prices. (OECD, 2008, Bonanno \& Lopez, 2012) Refusal of the transaction. Monopsonists can threaten to refuse their transactions thus seeking for more beneficial conditions. For example, proposing to purchase a greater quantity of goods for a price, corresponding to a significantly smaller amount. In such case suppliers merely cover their production costs, only ensuring the utilisation of their capacity. (Strobl \& Walsh, 2007, Barr \& Roy, 2008, Rotemberg, 2008, Brennan, 2011, Strobl \& Walsh, 2016)

We examined some aspects of distorted market competition in cases of monopsony and oligopsony. We also defined measures for reducing or eliminating their negative effect by taking advantage of the opportunities of international business negotiations. Further on it would be appropriate to examine the monopoly power of suppliers, ways to identify and assess them, as well as define the means to direct the balance of power towards the benefit of the buyer.

\section{Results}

\subsection{Identification of Monopoly and the Power of Supplier}

Purchasing procedures of various business entities often state that procurement should involve at least three participants submitting their offers. This assumption means that a higher number of suppliers allows to obtain a greater variety of solutions. In this case, the buyer makes use of the competitive tension. However, lack of competitive tension makes the situation completely different. One of the reasons resulting in a lack of competitive tension in the market is that the number of suppliers is not sufficient to create a free and open competition, as in case of a monopoly. Therefore, we could define market distortion as the absence of free and open competition. Free competition means that market participants are competing with each other, instead of cooperating to create and maintain a cartel. Open competition means that the market entry barriers are sufficiently low, thus making the profits of existing players rather low, because otherwise new entrants coming into the market would try to sell with lower profits, which would essentially be useful for customers and thus ensure their sales. (Mumuni et al., 2016, Lai et al., 2016, Shin, 2017)

Further on we will discuss the reasons for these market distortions $\square$ the market structure, market concentration and competition. Market structure. What number of market participants could ensure fair and open competition? Procurement rules of business entities often refer to the number " 3 ". However, three suppliers will not always guarantee competition. Monopoly refers to a situation, when there is only one supplier in the market, yet there are other reasons, which may put the buyer in de facto monopoly situations (Rogers, 2013, Mendoza, 2016, Matsumoto \& Szidarovszky, 2015, Kovac \& Zigic, 2016, Shin, 2017):

- restrictions for patents or intellectual property, which limit the ability of other suppliers to offer the same or a similar solution;

- the end user wants a particular supplier (with agents), thus limiting the freedom of choice;

- other solutions in the market are technically not acceptable for business;

- the costs of the supplier change are too high, making it impossible to change the supplier, as the costs would never pay back, making the buyer stay with the same supplier; 
- company policy may restrict purchases from specific countries or compel buying from a particular supplier, based on mutual trade agreements.

Market concentration. The fact that market offers only three suppliers, can hide the fact two of them may have divided the market, giving them the power to determine prices. The amount of suppliers in the market is not always the best reflection of the level on participants' competition. Therefore, a deeper analysis of the market structure should be done by examining four or more market participants. A small amount of companies dominating in the marked is referred to as oligopoly and defined by a concentration ratio of four entities, if the concentration ratio of the market competition of these four entities is above 40 percent. (Matsumoto \& Szidarovszky, 2015, Rogers, 2013, Kovac \& Zigic, 2016, Shin, 2017)

Competition level. Besides the number of suppliers in the market and the market structure, another important factor is the conditions under which suppliers compete with each other. And these are much more difficult to measure than the number of participants in the market or the market structure. Tender participants can take part under the buyer's rules and at the same time compete within the limits, mutually agreed on by several suppliers. (Lai et al., 2016, Mendoza, 2016, Shin, 2017) Although the activity aimed at reducing competition is illegal, it doesn't mean that cartels don't exist. The benefits of such agreements can often be much higher than the threat of a fine. And, finally, it's rather difficult to find and identify a cartel after all. Symptoms of cartel behaviour. There are three types of cartel (Rogers 2013, Lai et al., 2016, Mendoza, 2016, Matsumoto \& Szidarovszky, 2015):

- fixed price cartel;

- market sharing cartel;

- secret cartel of procurement participants.

Another alternative to a fixed price cartel could be sharing territory, where suppliers agree not to make proposals in the territory of another supplier. Therefore, a specific supplier can increase prices, knowing that competitors will not make any offers. (Mumuni et al., 2016, Shin, 2017) Another - even simpler - way of organising a cartel is agreeing not to sell to particular customers or particular clients in a specific area. Market sharing arrangements can take several forms. Suppliers may jointly decide on the number of procurements each of them can win. Accordingly, all suppliers do take part at procurements, but already know, which of the suppliers will sign the contract. Market sharing often occurs in markets with several dominating suppliers, as well as divided and uncoordinated buyers. (Lai et al., 2016, Mendoza, 2016, Matsumoto \& Szidarovszky, 2015)

In such cases, proving that the anti-competitive behaviour is determined by geography, logistics or other market characteristics, is not easy. Markets can also feature arrangements on price caps or discount level. Predictable buyers make it even easier to manipulate them in making proposals. Here are several examples:

- one or more participants refuse to submit proposals in order to help their competitor win;

- suppliers purposefully make offers that are not competitive or do not comply with procurement conditions;

- suppliers offer proposals, but participate in an agreed rotation on who will offer the best price, depending on who should win the contract. For example, the winner of the procurement changes every two years, even though the competitive advantages of the participants remain unchanged. 


\subsection{Defining of Global and Other Sources of Market Distortion}

Making a deal is easier than terminating it. There may be companies trying to get rid of unprofitable customers and focus their attention on profitable customers. Even if suppliers increase their prices, clients may find it impossible to replace them, because the replacement costs would be higher than the possible benefit of cooperation with another supplier. Thus, current suppliers continue to exploit their profitable buyers. (Braido \& Shalders, 2015) Suppliers may still seek to exploit their customers, no matter whether the market is distorted or not. Further on we will discuss possible questions, which may indicate whether a client is being exploited (Matsumoto \& Szidarovszky, 2015, Kovac \& Zigic, 2016, Rogers 2013):

- Is there a disproportion between increasing the annual expenditures and the demand or costs?

- Is the growth of supplier's prices faster than that of the price level of the services, influenced by inflation?

- Did the increase of supplier's prices reflect on increased quality of services?

- Are the requirements and / or additional charges higher than those of other suppliers in the same sector?

- Does the company's bookkeeping consider the impact of supplier's services to the company's profitability?

- Is there evidence that supplier's representatives are trying to influence our company's staff decisions?

- Is the supplier trying to pose restrictions using terms of the contract and specifications, which would limit us receiving these services?

- Does the supplier show inappropriate behaviour during negotiations, refusing to give discounts and seeking to maximize profits?

These questions and answers allow us to have a better understanding of whether suppliers exploit customers in their favour.

Procurement procedures often pose a requirement for competitive price offers and often require three proposals. If there are 10 potential suppliers of the relevant category and only three of them are invited to submit proposals, this leaves only a 30 percent probability of finding the best supplier. No procurement rules provide the demand for 10 proposals and procurement professionals will never invite only 3 random suppliers, so it is necessary to make a careful study of the market and consider potential suppliers from unexplored markets. Even in case of a monopoly, there may be some new participants that have just joined it. In order to find suitable suppliers one needs to assess the following sources of potential suppliers (Rogers, 2013, Mumuni et al., 2016, Lai et al., 2016, Shin, 2017):

- global catalogues of a specific category of online supply goods;

- consultations with specialists of a specific category of suppliers;

- communication with suppliers of the same category in other countries;

- exhibitions and presentations in other countries;

- market cooperation agencies or consultants;

- recruiting intermediaries to help find cheaper suppliers in other countries.

Looking for new suppliers can help expand available alternatives, thus increasing one's negotiating power as a buyer. Also, having more alternatives means expanding the existing market boundaries. (Antaki \& Kent, 2015, Alavoine \& Estieu, 2015, Kiryluk-Dryjska, 2016, Brett \& Thompson, 2016) This can be achieved by examining similar or related markets, which may become potential supplier markets. Sometimes other market participants find it quite difficult to switch to another market. Therefore, buyers looking for potential cheaper 
suppliers from other markets could think of possible negotiating proposals, which would make it easier to convince potential future partners cooperate in a new market (Rogers, 2013, Shin, 2017):

- sharing experience, such as attaching project managers or sharing some of the technology during joint meetings;

- subsidising certain costs of entry, buying appropriate measures, or otherwise investing into mutually-beneficial cooperation;

- offering a longer contract;

- gradually increasing the volume of orders and their complexity, thus giving the supplier an opportunity to adapt their own technology for more complex work.

Buyers often find themselves in an awkward position, when they need their suppliers more than the suppliers need them. Small customers may consider the possibility of closer cooperation with a monopoly enterprise, thus increasing their dependence. (Jablanovic, 2013, Willington \& Ning, 2014) This works in situations, where suppliers have a monopoly in several business areas, but not in all. Such measures can increase the available negotiating power. Of course, it is necessary to avoid situations, where one supplier can provide a full package of services. Therefore, it is important to divide the needed service into segments, creating more freedom of choosing from several suppliers, without giving all the negotiating powers to a single supplier. Or vice versa - a strategic move of the negotiations may include offering the supplier to sell more if they made a better offer. Suppliers' reputation. Some monopolistic suppliers have a firm hold of their market position, offering harsh reactions to any accusations of exploiting the situation for their own benefit. (Mirman et al., 2014, Braido \& Shalders, 2015, Sarafopoulos, 2015) The USA, Europe, Australia and Lithuania, intending to regulate markets and prevent the abuse of dominant market positions, introduced antitrust laws. For example, the United States has the Sherman Antitrust Act, the purpose of which is not to prevent certain companies from gaining a dominant position in certain fields, but rather to prevent artificial price increases both in supply and trade. Negotiators analysing the market situation frequently discuss the following issues (Rogers, 2013):

- Is there any evidence of inappropriate behaviour on behalf of the supplier(s)?

- Does the market feature a balance of different bargaining powers?

- Do suppliers abuse their privileged position?

- Is it possible to form an alliance with another group of buyers and cooperate?

\subsection{Distinguishing between Private and Business Interests}

Business relations are defined by a number of different aspects and can be defined by different — business, personal and contractual approaches (Table 1).

Table 1: Approaches to business relations

\begin{tabular}{lll}
\hline & Approaches to business relations & \\
\hline Business aspects & Personal aspects & Contractual aspects \\
& & \\
Bilateral risks and & Influence models & Agreement \\
opportunities & Number of interested parties & Specification \\
Sizes of the participants & Similar values & Agreement on the service \\
Matching goals & Degree of confidence & leve. \\
Balance of power & Personal sympathy & Sanctions \\
Supply chain & & Operational model \\
Incentives & & \\
\hline
\end{tabular}

Source: Mumuni et al. (2016), Rogers (2013) 
Buyers more often focus on business aspects, while sellers personal aspects and may influence business through specific individuals. This includes identification of key decisionmakers, analysis of their role, opportunities and position, as well as the relevant opportunities for influencing them and other relevant processes. There are several important aspects to be considered (Rogers, 2013):

- Is the supplier's management structure familiar?

- Are there any relationships with decision-makers?

- Do we know any people in contact with the supplier, and if not, whom should we get to know?

- What information should we provide?

Answers to these questions lead to a better understanding of the supplier and the current situation of the business entity.

Suppliers may increase their prices, knowing that the buyers of their goods and services or customers will not be able to get them anywhere else. Suppliers are often more inclined to offer better prices for customer groups than individual buyers. Of course, suppliers may also make offers that are not related to price. Price is not the only one negotiable criterion: there are many others that also contribute to the final result (Table 2). Purchasing managers are often only the third or fourth level employees at their organizations, making it possible to make an impact by influencing other participants, who occupy higher positions. (Mendoza, 2016) Making influence involves including other participants, related to the project. Opportunities arise, when buyers cooperate with representatives of their or their suppliers' organizations, which have a similar approach to potential cooperation opportunities. Persons drafting procurement specifications generally make a very significant impact on the freedom of choice and transactions.

Table 2: Additional negotiation criteria

Additional negotiation criteria

Turnover discount

Price stability

Price variation formula

Payment terms

Payment currency

Payment deferral

Shipping rates

Delivery deadlines

Delivery locations

Delivery frequency

Urgent cases

Maintenance contracts

Prices for spare parts

Return of excess goods
Installation fees
Operating costs
Instructions, drawings and plans
Training and support services
Safety and health issues
Packaging
Packaging return
Insurance
Specifications
Samples for testing
Translations
Guarantees

Advertising support

Priority under lack of goods

Package price

Wider range of guarantees

Special storage

Contract terms

Access to modifications/ additions

Confidentiality

Losses

Resources for common projects

Research

Provision of special equipment

Source: Developed by the authors according to Shin (2017), Rogers (2013)

It is necessary to examine the need for each specifications parameter, as this can tie the buyer to a particular supplier. Also, suppliers have experience in other markets, opening opportunities to cooperate in order to get into another market. In cases of monopoly, companies face situations, when they, refusing to buy from a specific supplier, can't get the product or service anywhere else. It is, therefore, likely for the company to start providing a certain product or service for themselves and for other market participants. However, this case is hardly possible, as the input costs for entering into a specific market may be too high.

There are several ways that may be useful depending on sales conditions. These are more tactical than strategic decisions and may force a monopolist or a cartel to increase their 
flexibility. In case of a regular need to purchase certain non-perishable products, we can buy quantities, which exceed the quantities we need in the current moment and later suddenly discontinue or significantly reduce the supply contracts. Suppliers may find such actions disturbing and be compelled to re-negotiate, while the exceeded volume of purchases will win some time for negotiations. Purchasing a larger amount for a longer period, such as six months, could become a sufficiently long period to draw suppliers' attention and thus could also help to obtain better conditions. However, here it would be necessary to evaluate storage costs as well. Ordering more or less at the end of the fiscal year could also draw suppliers' interest, since regular quantities were most likely already planned. However, it is most important to evaluate, how this would work out in the long run.

If the product demand is expected for a long term, companies may conclude long-term contracts. That is useful to suppliers intending to safeguard a regular, even if small income. Therefore, contract terms could include. (Rogers, 2013, Willington \& Ning, 2014):

- delivery terms, which must be financially weighed in order to pay off in the future;

- influence on prices (of course the supplier may raise them, but you need to minimise the changes). The price can be tethered to a particular index, but you need to be careful in selecting them, especially those that are constantly rising;

- cases for price decreases;

- limits for price rise over a specific time period;

- number of instances of price rise within a specific period of time.

In some cases it is possible to form a consortium of buyers with similar needs, providing them an opportunity to buy on behalf of all consortium participants and thus - a greater bargaining power. How long does it take to take a dominant market position? Months and even years. Thus, before making any impact on the market, it is necessary to consider the possible response of the enterprise's project managers. Most purchases involve several weeks, but it takes a long time to reset the balance of the market power. Of course, prices can be a result of intense competition, rather than a cartel. Symptoms of price fixing agreements include. (Braido \& Shalders, 2015, Rogers, 2013, Willington \& Ning, 2014):

- a certain price, applied only in certain areas or to specific customers;

- the same suppliers increase their prices at the same time, offering similar explanations for the rise;

- changes in prices of individual suppliers with no changes in determining factors;

- small discount system changes;

- one of the leading companies usually makes the first offer with the other companies making theirs later.

An alternative for a price cartel involves companies sharing territories or customers. For example, selecting customers in certain areas. Or making a consensus on which a certain undertaking will win a particular contract. Symptoms of such agreements include (Sarafopoulos, 2015, Rogers, 2013, Willington \& Ning, 2014):

- suppliers, competing in one territory, refuse to supply other areas, thus encouraging to buy from another supplier (with no specific reason);

- suppliers offering different prices in different areas and thus showing their competitiveness, which is not explained by market differences;

- supplier's confidence in success or that the other participant will not participate or will not offer competition (which is possible only in case of being in contact or potential agreements with the other competing participants). 
Market division often occurs in markets with a few dominant suppliers and uncoordinated buyers. Suppliers often claim that some areas make them less competitive due to geography, logistics or other market factors. There may be agreements, with suppliers submitting proposals according to common supplier agreements, knowing the lowest bidding threshold, discount system or price levels. More predictable buyers make it easier for suppliers to manipulate them in determining who will win (Bryde \& Shaldon, 2015, Sarafopoulos, 2015, Rogers, 2013, Willington \& Ning, 2014):

- suppliers choose not to compete in order to let another supplier win;

- suppliers make uncompetitive offers or do not meet specifications;

- suppliers submit proposals, but participate in a rotation, determining, whose turn it is to win the contract.

Buyers concerned that they may become victims of unfair competition should take note of the circumstances, which are not typical in competitive situations. These may include products, services or projects. (Bryde \& Shaldon 2015, Sarafopoulos, 2015, Rogers, 2013, Willington \& Ning, 2014):

- proposals that are less acceptable than usual (indicates that there is no tendency to move toward an agreement);

- proposals that are completely different from the company's available options;

- the same suppliers always provide the lowest price (over a long period of time);

- the winner of the contract hires other suppliers, which did not win the tender, as contractors;

- one supplier offers a very low price, making it difficult to explain, why the rest are so uncompetitive;

- one company is always very uncompetitive in a certain market, compared to other markets (and this cannot be explained by market and logistics factors);

- a new supplier entering the market results in fast and significant collective behaviour.

\section{Discussion}

The assessment of the negotiation powers of the negotiating parties is crucial for the development and implementation of effective international business negotiation strategies in order to make the best use of the negotiation potential. The theoretical researches are related to the assessment and development of negotiating power among participants at international business negotiations, as well as the scientific search for measures to ensure their effectiveness and the development of a scientifically-based, sustainable and effective negotiation power balancing system. Such a system could improve the efficiency of negotiating teams in distorted market competition. In practice new challenges appear in organizing business, increasing purposefulness of recent developments, which unfolds in increasing numbers of alternative business solutions and the need to search for new business partners, leading to greater expedience of business transactions, their efficiency and, ultimately, increasing the competitiveness of businesses entities in international business environment. Thus theoretical and practical relevance of this research can be characterized by the need to find and create a scientific basis for measures used for balancing negotiating powers among participants at business negotiations. These instruments should help to make an objective assessment of the negotiating powers and relationships between international business negotiation participants and their competitors, purposefully and effectively forming and using the negotiating powers of the negotiating team. These measures should guarantee a successful development and implementation of an effective business negotiation strategy in 
the context of international business development and increase its competitiveness, taking into account the circumstances, which distort market competition.

\section{Conclusion}

In this article, we examined aspects of distorted market competition in cases of monopsony, oligopsony and monopoly, which are significant for developing and implementing negotiating power in international business. One of the reasons for the lack of competitive tension in the market is an insufficient number of suppliers to create a free and open competition, such as in case of a monopoly. Therefore, we can refer to a distorted market as an absence of free and open competition. Free competition means that market participants are competing rather than cooperating with each other and forming cartel relations. Open competition means that the market entry barriers are sufficiently low, thus making the profits of existing players rather low, because otherwise new entrants coming into the market would try to sell with lower profits, which would essentially be useful for customers and thus ensure their sales.

The buyer power refers to how buyers or users can influence transaction terms with their suppliers. There are two types of power: monopsony power and bargaining power. If the buyer can reduce the price to the level lower than the market competition among suppliers, it means that he has the monopsony power. Negotiating power depends on the bargaining strength, demonstrated by the buyer during communication and negotiations with suppliers. Lower price is achieved from monopsonic power, rather than negotiating power. Negotiating power is used only when the supplier has a corresponding market power, which can be levered with negotiating power. The consequences of using negotiating power in each case are very different. Monopsony and oligopsony powers decrease the volume of sales and productivity in supply market, which ultimately has a negative effect on the consumer market. The negotiating power of the buyer is more of a compensatory nature. It increases the volume of production in supply market and can improve the market situation in the consumer market.

We also analysed measures, which help in situations of distorted market competition, reducing the negative impact on the balance of powers during international business negotiations. Some of the most important elements determining the balance of negotiating power include: market structure, market concentration and competition. Solving situations of distorted competition opens opportunities for international business, as the presence of other market participants can provide additional alternatives for reducing the negative impact of distorted competition on the balance of negotiating powers between negotiating parties. When the number of buyers and sellers is small, the negotiations may revolve regarding the possible excess profit between the buyer and the seller, according to their capacities. Excess profit distribution depends on the relative negotiating power. Being the goal of both buyers and sellers, excess profit encourages them to come to an agreement rather than seek for alternatives. Greater bargaining efficiency of the buyer opens him more possible alternatives, reducing the number of alternatives for the seller, thus allocating the greater share of the excess profit to the buyer. Buyers' transaction profit depends on their ability and willingness to look for alternative suppliers. Similarly, sellers' transaction profit depends on their ability and willingness to look for other buyers. The assessment of the negotiation powers of the negotiating parties is crucial for the development and implementation of an effective international business negotiation strategy in order to make the best use of the negotiation potential the negotiating power. 
The search for new suppliers can help expand the available alternatives, thus increasing buyers' negotiating power. Also, having more alternatives means expanding the existing market boundaries. This can be achieved by examining similar or related markets, which may become potential supplier markets. Sometimes other market participants find it quite difficult to switch to another market.

Therefore, buyers looking for potential cheaper suppliers from other markets could think of possible negotiating proposals, which would make it easier to convince potential future partners to cooperate in a new market: sharing experience, such as attaching project managers or sharing some of the technology during joint meetings; subsidising certain costs of entry, buying appropriate measures, or otherwise investing into mutually-beneficial cooperation; offering longer contracts; gradually increasing the volume of orders and their complexity, thus giving the supplier an opportunity to adapt their own technology for more complex work.

Buyers often find themselves in an awkward position, when they need their suppliers more than the suppliers need them. One may consider the possibility of closer cooperation with a monopoly enterprise, thus increasing one's dependence. This works in situations, where suppliers have a monopoly in several business areas, but not in all. Such measures can increase the available negotiating power. Of course, it is necessary to avoid situations, where one supplier can provide a full package of services. Therefore, it is important to divide the needed service into segments, creating more freedom of choosing from several suppliers, without giving all the negotiating powers to a single supplier. Or, on the contrary $\square$ a strategic move of the negotiations may include offering the supplier to sell more if they made a better offer.

\section{References}

Alavoine, C. \& Estieu, C. (2015). You can't always Get what you Want: Strategic Issues in Negotiation. Procedia - Social and Behavioral Sciences, 207(2), 335-343.

Antaki, Ch. \& Kent, A. (2015). Offering Alternatives as a Way of Issuing Directives to Children: Putting the Worse Option Last. Journal of Pragmatics, 78, 25-38.

Barr, T. \& Roy, U. (2008). The Effect of Labor Market Monopsony on Economic Growth. Journal of Macroeconomics, 30(4), 1446-1467.

Bonanno, A. \& Lopez, A.R. (2012). Wal-Mart's Monopsony Power in Metro and Non-Metro Labor Markets. Regional Science and Urban Economics, 42(4), 569-579.

Braido, L.H.B. \& Shalders, F.L. (2015). Monopoly Rents in Contestable Markets. Economics Letters, 130, 8992.

Brennan, T.J. (2011). Energy Efficiency and Renewables Policies: Promoting Efficiency or Facilitating Monopsony? Energy Policy, 39(7), 3954-3965.

Brett, J. \& Thompson, L. (2016). Negotiation. Organizational Behavior and Human Decision Processes, 136, 68-79.

Danziger, L. (2010). Endogenous Monopsony and the Perverse Effect of the Minimum Wage in Small Firms. Labour Economics, 17(1), 224-229.

Dassiou, X. \& Glycopantis, D. (2008). Price Discrimination Through Transactions Bundling: The Case of Monopsony. Journal of Mathematical Economics, 44(7-8), 672-681.

Dinkevych, E., Robert W., Tayfun A., Frank J. \& Prime, N. (2016). Can Outnumbered Negotiators Succeed? The Case of Intercultural Business Negotiations. International Business Review, 26(3), 592-603.

Dunne, T.C., Aaron, J.R., McDowell, W.C., Urban, J.D. \& Geho R.P. (2016). The Impact of Leadership on Small Business Innovativeness. Journal of Business Research, 69(11), 4876-4881.

Ghavami, S.M., Taleai, M. \& Arentze, T. (2016). Socially Rational Agents in Spatial Land Use Planning: A Heuristic Proposal Based Negotiation Mechanism. Computers, Environment and Urban Systems, 60, 67-78.

Jablanovic, V.D. (2013). The Chaotic Price Growth Model of the Agricultural Monopoly and New Information and Communication Technology. Procedia Technology, 8, 130-133.

Jager, A., Loschelder, D.D. \& Friese, M. (2017). Using Self-Regulation to Overcome the Detrimental Effects of Anger in Negotiations. Journal of Economic Psychology, 58, 31-43. 
Khakhar, P. \& Rammal, G.H. (2013). Culture and Business Networks: International Business Negotiations with Arab Managers. International Business Review, 22(3), 578-590.

Kiryluk-Dryjska, E. (2016). Negotiation Analysis Using the Theory of Moves-Theoretical Background and a Case Study. Journal of Policy Modeling, 38(1), 44-53.

Kovac, E. \& Zigic, K. (2016). Persistence of Monopoly, Innovation, and R\&D Spillovers. Research in Economics, 70(4), 714-734.

Lai, L., Wai, Ch., Kwong-wing Ch. \& Lorne, T.F. (2016). The Rise and Fall of the Sand Monopoly in Colonial Hong Kong. Ecological Economics, 128, 106-116.

Matsudaira, J.D. (2014). Monopsony in Health Labor Markets. Encyclopedia of Health Economics, San Diego: Anthony J. Culyer, Elsevier.

Akio, M. \& Szidarovszky, F. (2015). Learning Monopolies with Delayed Feedback on Price Expectations. Communications in Nonlinear Science and Numerical Simulation, 28(1-3), 151-165.

Mazeikiene, A., Peleckis, K. \& Peleckiene, V. (2012). Business Negotiations and Business Meetings: Communication in the Bargaining Process. Proceedings of the 7th International Scientific Conference "Business and Management 2012": Selected Papers. Vilnius, Lithuania, 683-692.

Mazeikiene, A., Peleckiene, V. \& Peleckis, K. (2010). The Main Factors Determining the Choice of SelfPresentation Strategies in Negotiations and Business Meetings. Business: Theory and Practice, 11(4), 353361.

Mazeikiene, A. \& Peleckis, K. (2010). Negotiation and Business Meetings: Strategies of Self-Presentation. Proceedings of The 6th International Scientific Conference "Business and Management" 2010: selected papers. Vilnius, Lithuania, 1033-1039.

Mazeikiene, A. \& Peleckis, K. (2010). Selection of Self-Presentation Strategies in Negotiations and Business Meetings: Factors Influencing the Choice. Proceedings of The 6th International Scientific Conference "Business and Management" 2010: selected papers, Vilnius, Lithuania, 1041-1049.

Mazeikiene, A. \& Peleckis, K. (2009) Strategies of Self - Presentation in the Business Meeting and Negotiation Business: Theory and Practice, 10(4), 322-329.

Mendoza, D.K.O. (2016). Antitrust in the New Economy Case Google Inc. Against Economic Competition on Web. Mexican Law Review, 8(2),1-29.

Mirman, L.J., Egas, M.S. \& Santugini, M. (2014). Noisy Signaling in Monopoly. International Review of Economics \& Finance, 29, 504-511.

Moosmayer, D.C., Chong Y-L.A., Liu, J.M. \& Schuppar, B. (2013). A Neural Network Approach to Predicting Price Negotiation Outcomes in Business-To-Business Contexts. Expert Systems with Applications, 40(8), 3028-3035.

Mumuni, A.G., Luqmani, M. \& Quraeshi, A.Z. (2016). Telecom Market Liberalization and Service Performance Outcomes of an Incumbent Monopoly. International Business Review, 26(2), 214-224.

OECD (2008). Policy Roundtables: Monopsony and Buyer Power. Competition Policy and Environment, 328.

Peleckis, K. (2016). Business Negotiations: Communication in Bargaining Process. Monograph. North Charleston, USA: CreateSpace, 224.

Peleckis, K. (2016). International Business Negotiation Strategies Based on Bargaining Power Assessment: The Case of Attracting Investments. Journal of Business Economics and Management, 17(6), 882-900.

Peleckis, K., Peleckiene, V., Peleckis, K. \& Polajeva, T. (2016). Towards Sustainable Entrepreneurship: Role of Nonverbal Communication in Business Negotiations. Entrepreneurship and Sustainability Issues, 4(2), 228239.

Petriwskyj, A., Gibson, A. \& Webby, G. (2015). Staff Members' Negotiation of Power in Client Engagement: Analysis of Practice Within an Australian Aged Care Service. Journal of Aging Studies, 33, 37-46.

Potocan, V., Nedelko, Z., Peleckiene, V. \& Peleckis, K. (2016). Values, Environmental Concern and Economic Concern as Predictors of Enterprise Environmental Responsiveness. Journal of Business Economics and Management, 17(5), 685-700.

Przybyła-Kasperek, M., \& Wakulicz-Deja, A. (2016). The Strength of Coalition in a Dispersed Decision Support System with Negotiations. European Journal of Operational Research, 252(3), 947-968.

Rogers, P. (2013). Dealing with Monopoly and Distorted Supply Markets, Leading Global Excellence in Procurement and Supply, FCIPS of PMMS consulting group. Easton House, 20.

Rotemberg, J.J. (2008). Minimally Altruistic Wages and Unemployment in a Matching Model with Monopsony. Journal of Monetary Economics, 55, 97-110.

Rufo, M.J., Jacinto, M. \& Perez, J.C. (2016). A Bayesian Negotiation Model for Quality and Price in a MultiConsumer Context. Reliability Engineering \& System Safety, 147, 132-141.

Sarafopoulos, G. (2015). Complexity in a Monopoly Market with a General Demand and Quadratic Cost Function. Procedia Economics and Finance, 19, 122-128. 
Schaerer, M., Loschelder, D.D. \& Swaab, R. (2016). Bargaining Zone Distortion in Negotiations: The Elusive Power of Multiple Alternatives. Organizational Behavior and Human Decision Processes, 137, 156-171.

Shin, E. (2017). Monopoly Pricing and Diffusion of Social Network Goods. Games and Economic Behavior, $102,162-178$

Strobl, E. \& Walsh, F. (2007). Dealing with Monopsony Power: Employment Subsidies vs. Minimum Wages. Economics Letters, 94(1), 83-89.

Weiss, A.-P.C. (2017). Negotiation: How to Be Effective. The Journal of Hand Surgery, 42(1), 53-56.

Wilken, R., Frank, J. \& Prime, N. (2013). The Ambiguous Role of Cultural Moderators in Intercultural Business Negotiations. International Business Review, 22(4), 736-753.

Willington, M. \& Ning, L.J. (2014). Regulating a Monopoly with Universal Service Obligations: The Role of Flexible Tariff Schemes. Telecommunications Policy, 38(1), 32-48. 